\title{
Herbaceous Layer Net Primary Production of Oak-Hornbeam Forest: Comparing Six Methods of Assessment Based on the Seasonal Dynamics of Biomass Increments
}

\author{
Mateusz Rawlik*๑ and Andrzej M. Jagodzińskiఠ \\ Institute of Dendrology, Polish Academy of Sciences, Parkowa 5, 62-035 Kórnik, Poland
}

\begin{abstract}
Proper estimation of the herb layer annual net primary production (ANPP) can help to appreciate the role of this layer in carbon assimilation and nutrient cycling. Simple methods of ANPP estimation often understate its value. More accurate methods take into account biomass increments of individual species but are more laborious. We conducted our study in an oak-hornbeam forest (site area $12 \mathrm{ha}$ ) dominated by beech in NW Poland during two growing seasons (2010 and 2011). We collected herb layer biomass from 7 to 10 square frames $(0.6 \times 0.6 \mathrm{~m})$. We collected plant biomass every week in April and May and every two weeks for the rest of the growing season. We compared six methods of calculating ANPP. The highest currentyear standing biomass (1st method of ANPP calculation) was obtained on May 15, 2010-37.8 $\mathrm{g} \mathrm{m}^{-2}$
\end{abstract}

Received 16 December 2020; accepted 16 May 2021;

published online 28 July 2021

Supplementary Information: The online version contains supplementary material available at https://doi.org/10.1007/s10021-021-0065 8-0.

Author contributions: MR-designed the research; formulated research problem and developed the methodology; collected the data; analyzed the data and wrote the first draft of the manuscript; contributed critically to the drafts and gave final approval for publication; AMJ-designed the research; formulated research problem; analyzed the data and contributed critically to the drafts and gave final approval for publication.

*Corresponding author; e-mail: mrawlik@man.poznan.pl and May 7, $2011-41.0 \mathrm{~g} \mathrm{~m}^{-2}$. The highest values of ANPP were obtained by the 6th method based on the sum of the highest products of shoot biomass and density for individual species: $74.3 \mathrm{~g} \mathrm{~m}^{-2}$ year $^{-1}$ in 2010 and $94.0 \mathrm{~g} \mathrm{~m}^{-2}$ year $^{-1}$ in 2011 . The spring ephemeral Anemone nemorosa had the highest share of ANPP with $50 \%$ of the total ANPP. Two summer-greens, Galeobdolon luteum and Galium odoratum, each had a ca. $10 \%$ share of ANPP. The best results of ANPP calculation resulted from laborious tracking of dynamics of biomass and density of individual shoots.

Key words: Herbaceous layer; Net primary production; Oak-hornbeam forest; Seasonal dynamic; Temperate deciduous forest; Spring ephemerals; Summer-greens.

\section{Abbreviation \\ ANPP Annual net primary production}

\section{HighLIGHTS}

- Herb species of fertile forests have various strategies for the use of light. 
- Herb species strategies are reflected in seasonal biomass dynamics.

- One time biomass peak sampling understates net production more than twofold.

\section{INTRODUCTION}

Herbaceous vegetation plays an underestimated role in forest ecosystems. From the viewpoint of total forest ecosystem biomass, the herb layer comprises only $1 \%$, and about $4 \%$ of net primary production (Muller 2014). However, herb layer foliage contains $30 \%$ more $\mathrm{N}$ and $\mathrm{P}$, twofold more $\mathrm{Mg}$ and threefold more K than tree foliage (Gilliam 2007; Welch and others 2007). Moreover, the biomass of the understory can reach values comparable to the biomass of leaves produced by the overstory (Landuyt and others 2020), which highlights the large contribution of the herbaceous layer to the labile part of the litter (Mayer 2008). Additionally, due to the fast decomposition of senescent plant tissues, the herb layer rapidly supplies nutrients to trees (Rawlik and others 2021). Due to rapid turnover, the herbaceous layer enhances leaf mass production by overstory trees (Elliott and others 2015). Herb vegetation can compete with tree seedlings for light (Franklin and others 2012; Thrippleton and others 2016). The herb layer contains a huge portion of forest biodiversity (Whigham 2004). Forest herbaceous species are often strictly connected with forests and do not occur elsewhere (Hermy and others 1999). Additionally, some forest herb species suffer from silvicultural systems applied on the landscape, for example forest tree stand rotations of less than 100 years, clearcuttings, and site preparation (Halpern and Spies 1995). Typically forest species have limited dispersal ability; hence, they are missing in post-agricultural forests (Hermy and Verheyen 2007). Temperate forests are subject to various pressures like eutrophication or acidification, global warming, increased grazing pressure, or invasions of alien species. Thus, herbaceous species are endangered in fragmented and transformed temperate forests in highly populated regions (Landuyt and others 2019). The herb layer is also a habitat and forage source for arthropods and ungulates (Dzięciołowski 1970; Boch and others 2013; Smolko and others 2018). The role of the herb layer is unappreciated in many ways, so one point of its significance is proper estimation of its contribution to biomass production, which allows us to properly define the herb layer role in carbon assimilation and nutrient cycling.
Oak-hornbeam forests are a common type of temperate deciduous forests in Europe. Temperate deciduous forests occur in areas with a distinct climate seasonality and are common in Europe, eastern North America, and eastern Asia (Reich and Frelich 2002). Average annual temperature for the temperate deciduous forest biome is $8.6{ }^{\circ} \mathrm{C}$ and is characterized by distinct seasonality with average winter temperatures of $2.9{ }^{\circ} \mathrm{C}$, and summer temperatures of $19.3{ }^{\circ} \mathrm{C}$ (Hanes and others 2013). Sum of annual precipitation reaches $500-2000 \mathrm{~mm}$ (Woodward and others 2004). During the cold period trees fall into dormancy and leaves are shed, causing changes in light conditions on the forest floor during the year. Herbaceous vegetation starts growth in spring before full canopy closure and uses favorable light conditions on the forest floor. The main tree species occurring in central Europe forests are: oaks (Quercus robur and Q. petraea), beech (Fagus sylvatica), limes (Tilia cordata, $T$. platyphyllos), hornbeam (Carpinus betulus), maples (Acer pseudoplatanus, Acer platanoides) (Jacob and others 2010), and on wetter sites: elms (Ulmus minor, U. laevis), ash (Fraxinus excelsior), and alders (Alnus glutinosa, A. incana) (Schnitzler and others 2007).

Light limitation on the forest floor is a major factor determining herbaceous plant composition and biomass (Axmanová and others 2011). The light conditions are variable during the growing season in deciduous forests. Due to canopy closure at the turn of April and May the amount of light reaching the forest floor decreases $75-80 \%$ (Jagodziński and others 2016). Herbaceous plants of mesic and euthrophic deciduous forest floors represent two general strategies: spring ephemerals which avoid shading by the tree canopy and summer-greens which are adapted to shade. Spring ephemerals develop aboveground organs and assimilate carbon in the period before full canopy closure, at which time the shoots senesce and the plants fall into dormancy as belowground storage organs. Summer-greens develop aboveground organs during the whole growing season and are adapted to shade (Rawlik and Jagodziński 2020; Uemura 1994). Spring ephemerals are characterized by higher photosynthetic capacity than summer-greens, but summer-greens have higher efficiency of photosystem II in semi-shaded and shaded conditions (Popović and others 2016). Leaves of spring ephemerals are characterized by high compensation points, high saturation points, and high dark respiration rates. Additionally, suntype leaves of spring ephemerals have well-developed palisade mesophyll and high chlorophyll a/b 
ratios (Neufeld and Young 2014). In general, spring ephemerals have thicker leaves (higher specific leaf area) than summer-greens (Jagodziński and others 2016). In contrast, leaves of summer-greens are characterized by higher chlorophyll contents per dry mass, lower compensation points, lower saturation points, well-developed spongy parenchyma, and have more matt leaves than spring ephemerals (Neufeld and Young 2014).

The simplest method to estimate annual net primary production (ANPP) is to measure the amount of biomass produced during the year (Clark and others 2001). In the case of annual plants or shoots, ANPP is the amount of biomass at the time when it reaches its peak. Most often the highest amount of herbaceous layer in oak-hornbeam forests is in the range of $20-80 \mathrm{~g} \mathrm{~m}^{-2}$. For example, in oak-hornbeam forests of Białowieża National Park (E Poland) herb layer biomass amounted to $20.4 \mathrm{~g} \mathrm{~m}^{-2}$ (Dabrowski 1953), in southern Wielkopolska (Central Poland) - 33.8 $\mathrm{g} \mathrm{m}^{-2}$ (Jagodziński and others 2013), West Pomerania (NW Poland)-39.4 $\mathrm{g} \mathrm{m}^{-2}$ (Rawlik and others 2012), Niepołomicka forest (S Poland)-44.6 $\mathrm{g} \mathrm{m}^{-2}$ (Banasik 1978), in Slovakia, in oak-hornbeam forests-43-75 $\mathrm{g} \mathrm{m}^{-2}$ (Kollár and others 2010), and in the Netherlands, as high as $134 \mathrm{~g} \mathrm{~m}^{-2}$ (Werger and van Laar 1985). Lower amounts of herb layer biomass were noted from acidic and shaded beech forest in $\mathrm{S}$ Poland-4.4 $\mathrm{g} \mathrm{m}^{-2}$ (Rajchel 1965), and in Slovakia-4.1 $\mathrm{g} \mathrm{m}^{-2}$ (Kubíček and Jurko 1975). Higher amounts of herb layer biomass were usually noted in moist and fertile riparian forest dominated by black alder: $107.5 \mathrm{~g} \mathrm{~m}^{-2}$ in riparian alder forest in Białowieża National Park (E Poland) (Aulak 1970), and in Slovakian black alder forest-136.4 $\mathrm{g} \mathrm{m}^{-2}$ (Kubíček and Jurko 1975). Assessing biomass of the herb layer at one time has limitations. Due to different times at which various species reach maximal biomass, the one peak value of whole herb layer biomass may underestimate ANPP. This is especially the case in deciduous forests where peak biomass of spring ephemerals occurs during late May and early June and peak biomass of summer-greens occurs in early autumn (Rawlik and Jagodziński 2020). An advantageous method for estimating the herb layer ANPP was proposed by Traczyk (1967a, b), who suggested determining herb biomass by multiplying the shoot density and shoot biomass measured independently in the field. Due to high spatial variability of plant biomass distribution, many samples are needed to obtain the reliable results. But it is not necessary to measure the biomass of plants in each sample plot; it is enough to know mean shoot biomass based on several dozen measurements of shoots. To take into account different times at which biomass peaks among species, this author suggested estimating shoot biomass at the time just after the most flowers blossom. Other factors which influence ANPP underestimation are herbivory, mortality, and biomass losses between sampling times (Clark and others 2001), which are difficult to measure.

Only a few of the above-mentioned studies focused on the seasonal dynamics of herbaceous biomass. Therefore, there is no information about the full seasonal dynamics of understory biomass in temperate oak-hornbeam forests. Thus, we aimed to describe seasonal fluctuations of whole herb layer biomass and individual species. We also present the dynamics of shoot density and shoot biomass during two growing seasons. Estimation of herbaceous layer ANPP is rare in the literature. Based on our results, we present six ways of calculating the ANPP. This procedure allowed for the comparison of ANPP values based on methods requiring different amounts of work. Moreover, they also answer the question: what timing of measurements should be used for calculations? Thus, the results of our studies can help in planning future studies, as they help to choose the most useful method of ANPP calculation.

We hypothesized that biomass of herbaceous species has two peaks during the vegetation season, due to seasonal changes in dominance and biomass production in this layer by two groups of plants (spring ephemerals and summer-greens) (Jagodziński and others 2013; Rawlik and others 2012). Furthermore, individual species reach their biomass peak at different times of the growing season; therefore, an accurate estimate of the ANPP requires tracking the biomass dynamics of particular populations. Finally, methods based on one to a few collection times give underestimated results of ANPP in comparison with methods based on multiple collection times for biomass estimations.

\section{Material AND Methods}

\section{Study Site}

The study was conducted in an oak-hornbeam forest association (Stellario holosteae-Carpinetum betuli) with dominance by beech (Rawlik and others 2012). The research site (ca. 12 ha) was located in the Różańsko Forest District (NW Poland, $\left.52^{\circ} 52^{\prime} 30^{\prime \prime} \mathrm{N}, 14^{\circ} 45^{\prime} 22^{\prime \prime} \mathrm{E}\right)$. According to the physio-geographical regionalization, the study site was 
located in the Southern Baltic Lake Districts (Solon and others 2018). The soils of the study site were developed from boulder clays. Beech trees about 100 years old were dominants in the canopy layer (Plan Urządzenia Lasu 2006). Tree stand characteristics were described based on diameter at breast height $(1.30 \mathrm{~m})$ measurements on four 0.25 ha $(50 \times 50 \mathrm{~m})$ sample plots (Table 1). All trees that were at least $1.30 \mathrm{~m}$ tall and greater than $7 \mathrm{~cm}$ diameter at $1.30 \mathrm{~m}$ were measured.

The mean annual temperature during 19712010 was $8.8{ }^{\circ} \mathrm{C}$ and the annual sum of precipitation was $541 \mathrm{~mm}$. During the years in which fieldwork was conducted (2010-2011), mean annual temperature was $8.8{ }^{\circ} \mathrm{C}$ and the annual sum of precipitation was $615 \mathrm{~mm}$, based on data from the Gorzów Wielkopolski meteorological station (ca. $35 \mathrm{~km} \mathrm{SE}$ of the study site; Central Statistical Office 2011, 2012; Rawlik and Jagodziński 2020). Monthly mean temperatures during the two growing seasons (based on temperatures measured hourly by two HOBO sensors located in the study site at $0.5 \mathrm{~m}$ height above ground level), and monthly sums of precipitation, based on data from the Myślibórz meteorological station (ca. $10 \mathrm{~km} \mathrm{NE}$ of the research site, IMGW-PIB 2020, https://dane publiczne.imgw.pl/data/dane_pomiarowo_obserwa cyjne/) are presented in Table 2.

\section{Sample Collection in the Study Site and Laboratory Methods}

The herb layer samples were collected from square frames with an area of $0.36 \mathrm{~m}^{2}(0.6 \times 0.6 \mathrm{~m})$. All plants were cut at the soil level; thus, we collected all of the aboveground biomass. If a shoot was rooted inside the frame, then the whole plant was included in the sample even if some parts were outside of the frame. In complementary fashion, if a shoot was rooted outside the frame but some parts were inside the frame, that shoot was ex-
Table 2. Mean Air Temperature $\left({ }^{\circ} \mathrm{C}\right)$ and the Monthly Sum of Precipitation (mm) During the Growing Seasons of 2010 and 2011.

\begin{tabular}{lrrrrr}
\hline Month & \multicolumn{2}{c}{ Temperature $\left({ }^{\circ} \mathrm{C}\right)$} & & \multicolumn{2}{c}{ Precipitation $(\mathrm{mm})$} \\
\cline { 2 - 3 } \cline { 6 - 6 } & $\mathbf{2 0 1 0}$ & $\mathbf{2 0 1 1}$ & & $\mathbf{2 0 1 0}$ & $\mathbf{2 0 1 1}$ \\
\hline April & 9.77 & 12.53 & & 38.9 & 16.8 \\
May & 11.00 & 13.96 & & 88.4 & 30.1 \\
June & 16.42 & 17.64 & & 32.9 & 35.8 \\
July & 20.32 & 16.78 & & 82.6 & 220.6 \\
August & 17.14 & 17.38 & & 202.5 & 44.6 \\
September & 12.40 & 14.38 & & 66.1 & 69.5 \\
October & 7.18 & 9.11 & & 17.2 & 42.9 \\
\hline
\end{tabular}

cluded from the sample. At each collection time, we collected 7 to 9 frames from the study area in 2010, and 10 frames in 2011. At each collection time frames were distributed randomly throughout the whole research site (ca. $12 \mathrm{ha}$ ). We limited the study area to homogenous conditions of herb layer vegetation. The vegetation of the study area was described by Rawlik and others (2012). We started sampling when the growing season started, on March 20, 2010, and March 19, 2011. Growing season was defined as the period when daily mean temperature reaches or exceeds $5{ }^{\circ} \mathrm{C}$. In April and May 2010 and March, April, and May 2011 we collected plant material every 7 days. In June, July, August, September, October, and November we collected plant material every 14 days. The last collection time was at the end of the vegetation season, on October 30, 2010, and November 12, 2011. In total, we collected samples 21 times in 2010 and 24 times in 2011.

The sample plots were randomly located throughout the whole study site. The location of sample plots was marked on the map for each time of collection. The sample plots were not located in the same place twice. In the field, each species was

Table 1. Tree Stand Characteristics of the Study Site.

\begin{tabular}{|c|c|c|c|}
\hline Tree species & Basal area $\left(\mathrm{m}^{2} \mathrm{ha}^{-1}\right)$ & Mean diameter at breast height $(\mathrm{cm})$ & Trees density $\left(\mathrm{ha}^{-1}\right)$ \\
\hline Fagus sylvatica & 17.7 & 25.9 & 237 \\
\hline Carpinus betulus & 8.3 & 35.9 & 75 \\
\hline Quercus robur & 6.1 & 88.9 & 9 \\
\hline Acer pseudoplatanus & 1.6 & 16.0 & 67 \\
\hline Fraxinus excelsior & 0.6 & 27.6 & 8 \\
\hline Larix decidua & 0.5 & 29.2 & 7 \\
\hline Pseudotsuga menziesii & 0.1 & - & 1 \\
\hline Tilia cordata & 0.05 & - & 1 \\
\hline
\end{tabular}


collected separately in each frame, placed in a paper bag, and labeled by species, frame, and collection date. Additionally, for each vascular plant species we determined the number of shoots inside the frame; thus, we can calculate shoot density per unit area. In the case of perennial plants (tree saplings, shrubs, wintergreens) we separated the current year's increment from the rest of the plant which had grown in previous years. Thus, we put the current year's increment and increment from previous years into separate paper bags. In the case of clonal plants, we determined the density of flowering and vegetative shoots and we collected these shoots into separate bags. For laboratory measurements from each sample plot for each species (and for flowering and vegetative shoots, if applicable), a maximum of 30 shoots or all harvested shoots if there were less than 30 shoots in the frame were placed separately on blotting paper for biomass measurements of individual shoots.

After field collection samples were transported to the laboratory of the Institute of Dendrology PAS in Kórnik and put in a dryer with forced air circulation (ULE 600, Memmert GmbH + Co.KG, Germany) and dried at $65{ }^{\circ} \mathrm{C}$ to constant weight (at least 7 days). If dried samples were stored, then they were put into the dryer again for one day just before measuring the sample mass. After drying, samples were allowed to obtain room temperature and then weighed. Mass measurements were taken using a BP 210 S, Sartorius, Göttingen, Germany; (https://www.sartorius.dataweigh.com) with $0.0001 \mathrm{~g}$ accuracy.

\section{Methods of ANPP Assessment}

We used six methods to calculate ANPP according to modified proposals by Aulak (1976). The 1st method was to assume that the ANPP was the highest current-year biomass level of the whole herb layer. The 2 nd method was based on the sum of positive differences between biomass values between collection times. In the 3rd method, ANPP was the sum of biomass peaks by each species occurring throughout the growing season. The next three methods were based on the product of shoot density and shoot biomass at different times. The 4th method used the product of shoot density and shoot biomass at the collection time when the shoot biomass was the highest. The 5th method used the collection time when the shoot density was the highest and the 6th method used the time when the product of shoot density and shoot biomass was the highest.

\section{Statistical Analyses}

For determination of differences of mean biomass among times of collection for each year (2010 or 2011), we used a Kruskal-Wallis test with a post hoc test (Tibco Software Inc. 1984-2017, Statistica 13.3). The mean biomass of shoots at harvest time was determined based on the mean weighted by the number of shoots. For cases when we separately measured flowering and vegetative shoots (for example, for Anemone nemorosa, Ficaria verna, and Galium odoratum), first we calculated the mean weighted by the number of shoots for a sample and next calculated mean weighted by shoot number for a collection time.

We used the following formulas:

$$
B_{\text {samp }}=\frac{B_{f} \times N_{f}+B_{v} \times N_{v}}{N_{f}+N_{v}}
$$

$B_{\text {samp }}$ mean shoot biomass in a sample, $B_{\mathrm{f}}$ mean flowering shoot biomass in a sample, $N_{\mathrm{f}}$ number of flowering shoots in a sample, $B_{\mathrm{v}}$ mean vegetative shoot biomass in a sample, $N_{\mathrm{v}}$ number of vegetative shoots in a sample,

$$
B_{\text {mean }}=\frac{\sum_{n}^{i=1} B_{\text {samp }_{n}} \times N_{n}}{\sum_{n}^{i=1} N_{n}}
$$

$B_{\text {mean }}$ mean shoot biomass weighted by shoot number at time of collection, $B_{\text {samp mean shoot }}$ biomass in a sample, $N$ number of shoots in a sample, $n$ number of sample plots.

For mean shoot biomass, mean density, and mean biomass we calculated standard error shown in figures using Statistica (Tibco Software Inc. 1984-2017, Statistica 13.3).

\section{Results}

The Kruskal-Wallis test showed statistically significant differences in current-year herb layer biomass amounts among times of collection $\left(\chi^{2} 72.4206\right.$, $p<0.0001$ in 2010; $\chi^{2} 111.2000, p<0.0001$ in 2011) (Table Al). Using a post hoc test, which indicated statistical differences at $p<0.05$, the highest biomass in 2010 was observed May 15 and differed significantly from the lowest values observed March 20, August 21, and October 30. In 2011 the highest biomass was observed May 7 and differed significantly from the lowest values observed March 19, March 26, June 25, July 23, August 6, August 20, October 29, and November 12 (Table Al).

All six methods of ANPP estimation showed higher ANPP in 2011 than in 2010. The differences 
in ANPP between the two years were 8 to 38 percent (Table 3). In both years the lowest values were obtained by the 1st method based on maximal current-year stand biomass: $37.8 \mathrm{~g} \mathrm{~m}^{-2}$ year $^{-1}$ in 2010 and $41.0 \mathrm{~g} \mathrm{~m}^{-2}$ year $^{-1}$ in 2011 (Table 3). The dominant share in biomass peaks were spring ephemerals. In both years they were responsible for over $30 \mathrm{~g} \mathrm{~m}^{-2}$ year $^{-1}$, while at the same time summer-greens amounted to $5.6 \mathrm{~g} \mathrm{~m}^{-2}$ year $^{-1}$ in 2010 and $8.8 \mathrm{~g} \mathrm{~m}^{-2}$ year $^{-1}$ in 2011 (Figure 1).

Estimation of the ANPP based on the sum of positive differences between consecutive values at times of biomass collection (2nd method) had ANPP values higher by $33 \%$ and $39 \%$ (respectively, in 2010 and 2011) than the 1st method (Table 3, A2). The highest biomass increment was noted between April 3 and 10, $2010\left(13.7 \mathrm{~g} \mathrm{~m}^{-2}\right)$, and between April 9 and 16, $2011\left(12.8 \mathrm{~g} \mathrm{~m}^{-2}\right)$ (Table A2).

The 3rd method based on the sum of biomass peaks of individual species had ANPP values 58\% (2010) and 77\% (2011) higher in comparison with the lst method (Table 3 ). The spring ephemeral Anemone nemorosa had the highest share of ANPP equal to $41 \%$ of total ANPP in 2010 and $43 \%$ in 2011. Summer-greens had lower shares of the total ANPP estimated by the 3rd method: Galeobdolon luteum equal to $9 \%$ in 2010 and $11 \%$ in 2011 ; Galium odoratum reached $6 \%$ in 2010 and $8 \%$ in 2011; and Mercurialis perennis reached $11 \%$ in 2010 and 3\% in 2011 (Table A3). The Anemone nemorosa biomass peak was obtained May 15, 2010, and April 30, 2011, for Galeobdolon luteum the biomass peak was October 2, 2010, and September 17, 2011, for Galium odoratum the biomass peak was August 7, 2010 and October 15, 2011, for Mercuri- alis perennis the biomass peak was June 26, 2010 , and July 9, 2011 (Figure 2, Table A3).

The next three methods (4th, 5th, and 6th methods) were based on the sums of products of mean shoot density and mean shoot biomass for individual species. They were differentiated by the time of biomass collection which was used for calculations. The 4th method used values of shoot density and shoot biomass at the time when the shoot biomass was highest. The resulting ANPP values were 39\% (2010) and 77\% (2011) higher in comparison with 1st method, but were $12 \%$ lower than values obtained by the 3rd method (in 2010) or similar to values obtained by the 3rd method in 2011 (less than $0.1 \%$ difference) (Table 3). Spring ephemerals had the highest share of ANPP: Anemone nemorosa reached $57 \%$ of the total ANPP in 2010 and $63 \%$ in 2011 ; Ficaria verna reached $6 \%$ in 2010 and 8\% in 2011; and summer-greens: Galeobdolon luteum reached $10 \%$ in both 2010 and 2011; Galium odoratum reached 7\% in 2010 and $2 \%$ in 2011 (Table A4). The shoot biomass peak of Anemone nemorosa was obtained on May 7, 2010, and May 8, 2011. The shoot biomass peak value obtained in 2011 (0.0520 g) was 30\% higher than the shoot biomass peak value in 2010 (0.0399 g) (Figure 3), and additionally at the same time shoot density was $17 \%$ higher in $2011\left(878.33 \mathrm{~m}^{-2}\right)$ than in $2010\left(752.78 \mathrm{~m}^{-2}\right.$ ) (Table A4). Thus, the ANPP of Anemone nemorosa in 2011 was over $15 \mathrm{~g} \mathrm{~m}^{-2}$ year ${ }^{-1}$ higher than in 2010 and was responsible for $78 \%$ of the difference in total ANPP between the years 2010 and 2011 (Tables 3, A4). The summergreens (for example Galeobdolon luteum and Galium odoratum) had over twofold higher shoot biomass than spring ephemerals (Anemone nemorosa and Ficaria verna) (Figure 3, Table A4) but the shoot

Table 3. ANPP Values Estimated by Six Methods for Two Growing Seasons-2010 and 2011, and Differences Between Estimations for Two Years in $\mathrm{g} \mathrm{m}^{-2}$ year $^{-1}$ and Percentages.

\begin{tabular}{lllll}
\hline Method & $\begin{array}{l}\text { The ANPP in } \\
\text { 2010 year } \\
\left(\mathrm{g} \mathrm{m}^{-2} \text { year }^{-1}\right)\end{array}$ & $\begin{array}{l}\text { The ANPP in } \\
\text { 2011 year } \\
\left(\mathrm{g} \mathrm{m}^{-2} \text { year }^{-1}\right)\end{array}$ & $\begin{array}{l}\text { Differences between } \\
\text { the ANPP for 2011 and } \\
\text { 2010 year }\left(\mathrm{g} \mathrm{m}^{-2} \text { year }^{-1}\right)\end{array}$ & $\begin{array}{l}\text { The percentage ratio } \\
\text { of the ANPP in 2011 } \\
\text { and } 2010 \text { year }(\%)\end{array}$ \\
\hline 1st & 37.835 & 41.027 & 3.192 & 108 \\
2nd & 50.249 & 58.261 & 8.012 & 116 \\
3rd & 59.783 & 72.594 & 12.811 & 121 \\
4th & 52.680 & 72.654 & 19.974 & 138 \\
5th & 52.105 & 68.611 & 16.506 & 126 \\
6th & 74.307 & 93.958 & 19.651 & 126
\end{tabular}

Description of methods: 1st-the maximal value of biomass during the growing season; 2 nd-the sum of positive differences between consecutive times of biomass collection; $3 \mathrm{rd}$-the sum of maximal biomasses of individual species; 4 th—the sum of products of shoot biomass and density at the time of the highest shoot biomass; 5 th-the sum of products of shoot biomass and density at the time of the highest shoot density; 6th-the sum of products of shoot biomass and density at the time of the highest product of shoot biomass and density. 


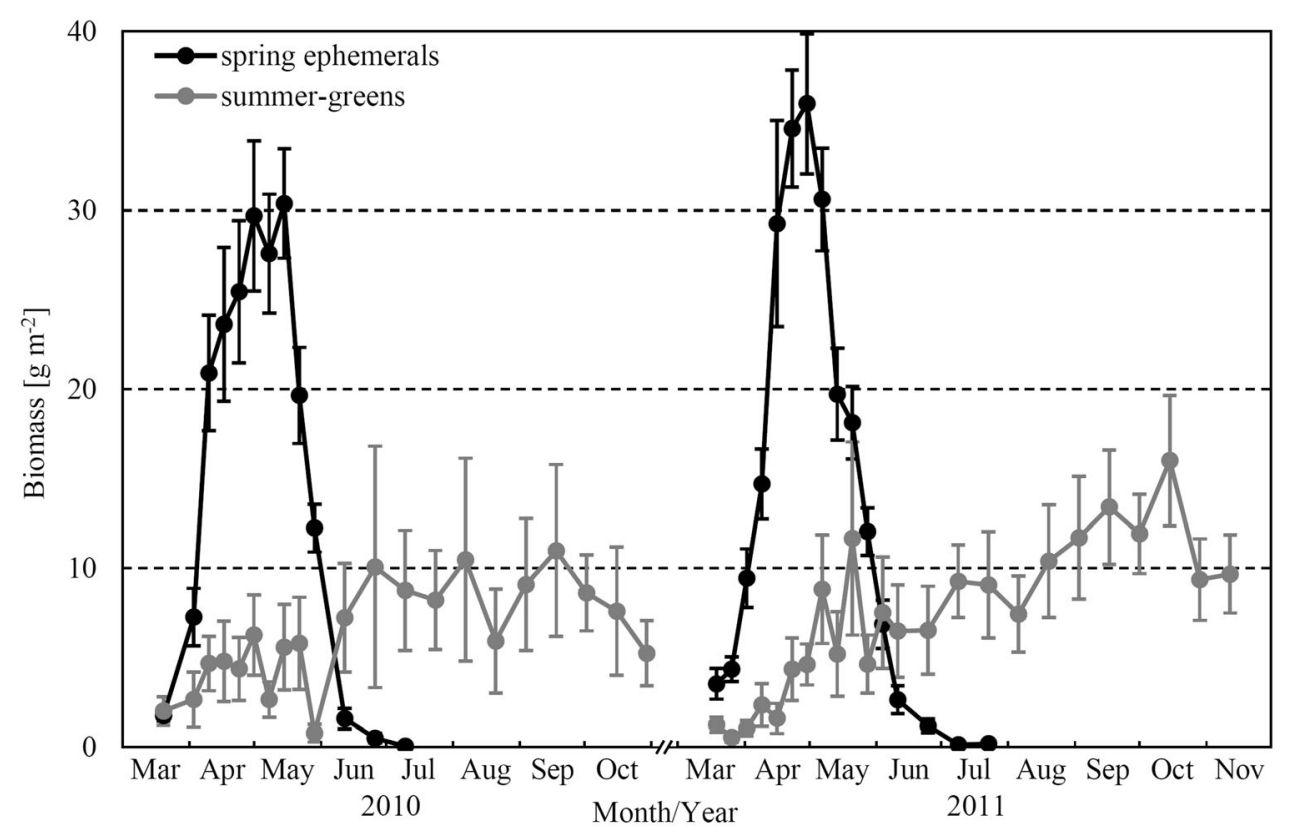

Figure 1. The seasonal dynamics of the biomass of spring ephemerals and summer-greens. The points represent mean values and the vertical lines represent the standard error of the mean.

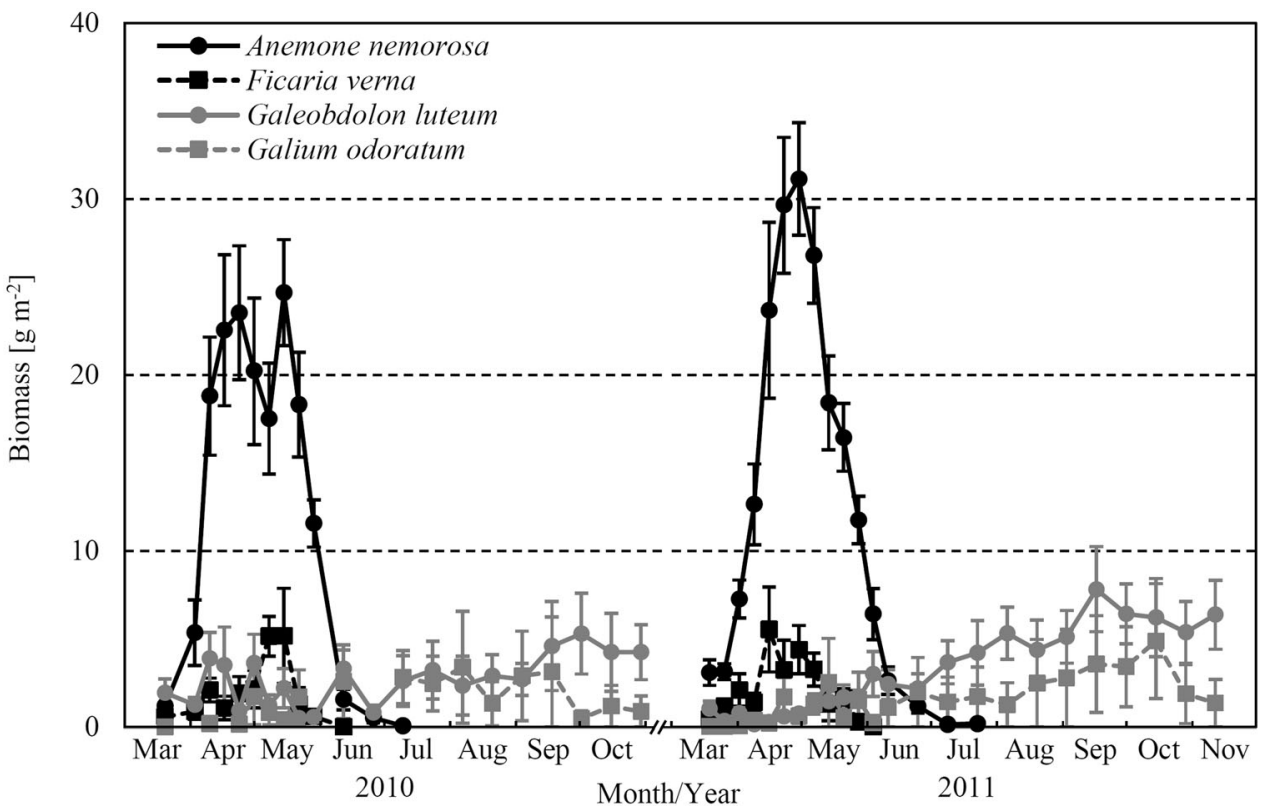

Figure 2. The seasonal dynamics of the biomass of dominant herb layer species: two spring ephemerals: Anemone nemorosa and Ficaria verna, and two summer-greens: Galeobdolon luteum and Galium odoratum. The points represent mean values and the vertical lines represent standard error of the mean.

density of summer-greens was considerably lower (even 10 times) (Figure 4, Table A4).

The 5th method used the products of shoot density and shoot biomass at the time when the shoot density was highest. The values of the ANPP obtained were $38 \%$ higher in 2010 and $67 \%$ higher in 2011 than the values obtained by the 1st method
(Table 3). In comparison with the 4th method the differences were $1 \%$ less in 2010 and $6 \%$ less in 2011 (Table 3). The highest share of the ANPP was the spring ephemeral Anemone nemorosa that was responsible for $47 \%$ of the total ANPP in 2010 and $43 \%$ in 2011 . Among summer-greens, Galeobdolon luteum was responsible for $13 \%$ of the total ANPP in 


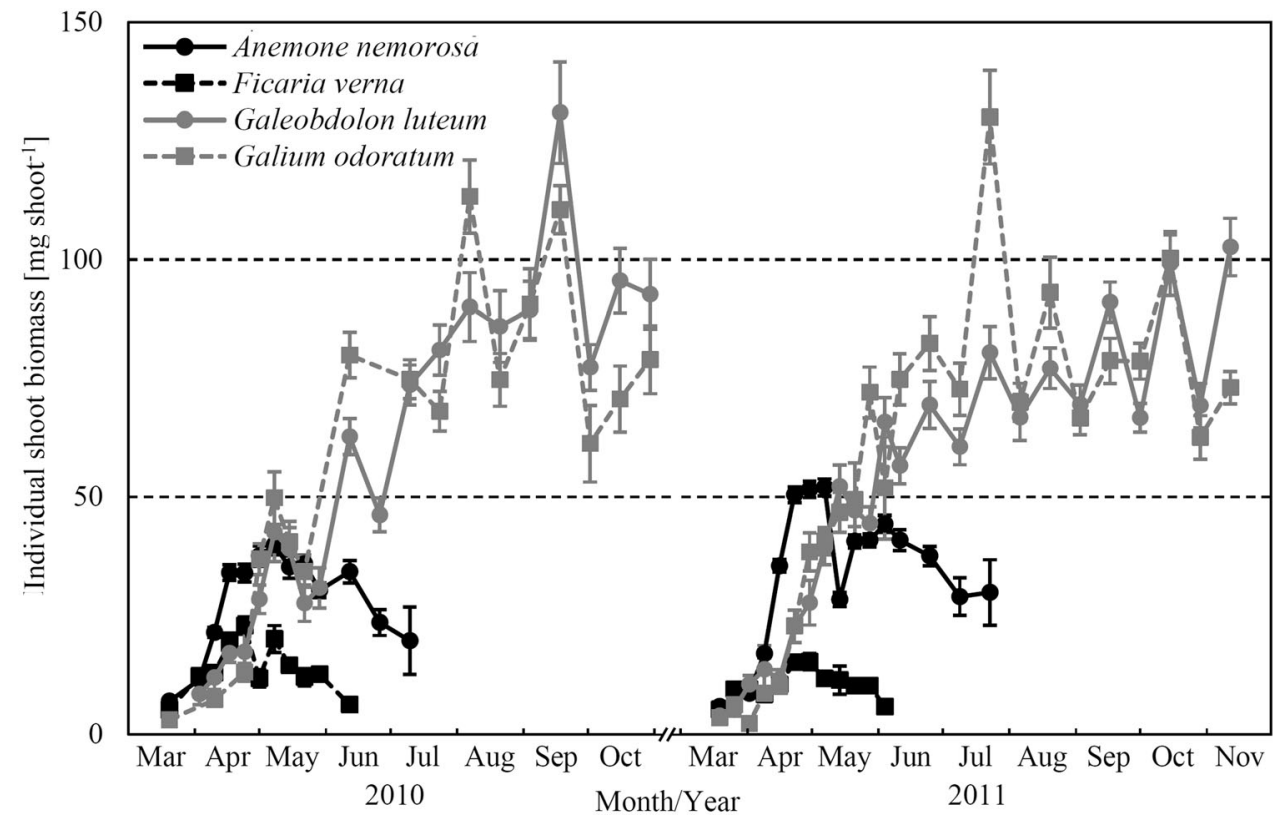

Figure 3. The seasonal dynamics of shoot biomass of dominant herb layer species: two spring ephemerals: Anemone nemorosa and Ficaria verna, and two summer-greens: Galeobdolon luteum and Galium odoratum. The points represent mean values and the vertical lines represent the standard error of the mean.

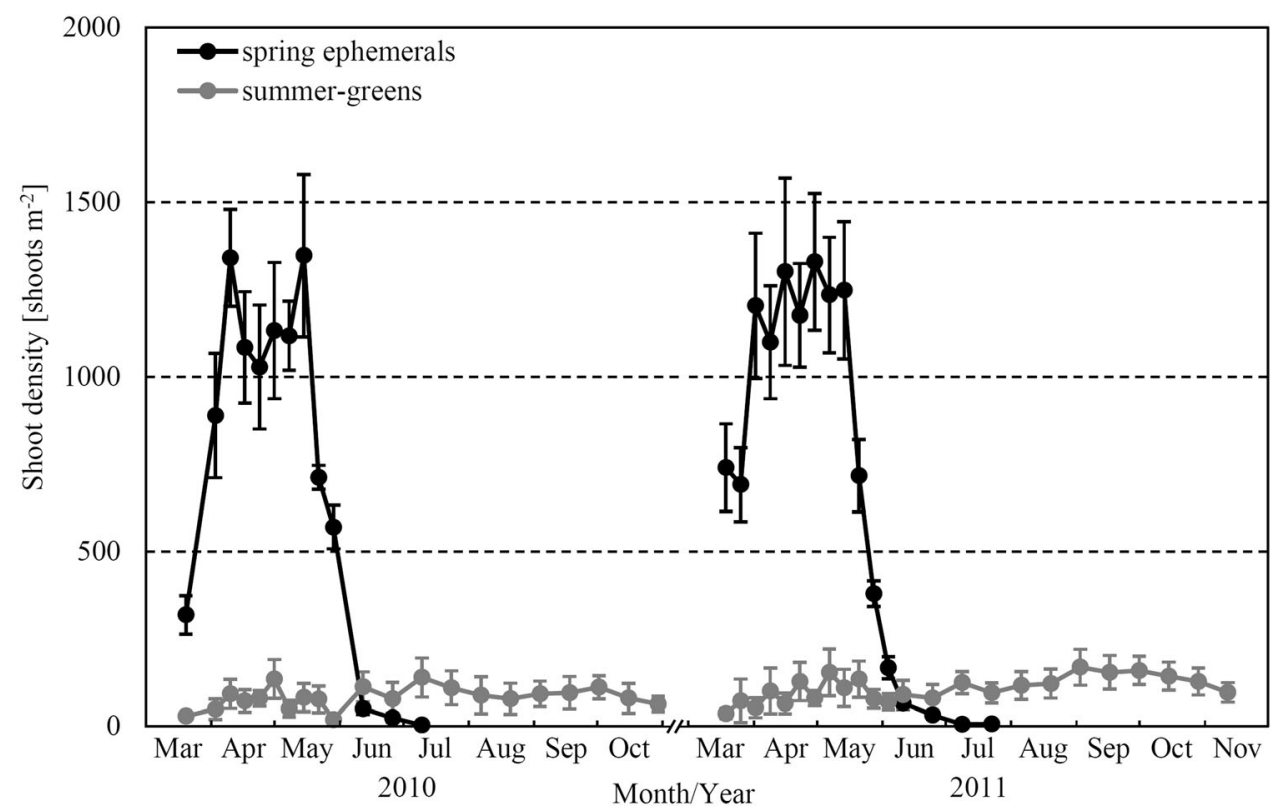

Figure 4. The seasonal dynamics of shoot densities of spring ephemerals and summer-greens. The points represent mean values and the vertical lines represent the standard error of the mean.

2010 and $10 \%$ in 2011 , and Galium odoratum for $4 \%$ in 2010 and $9 \%$ in 2011 . The shoot density peak for spring ephemerals was observed in April and May and significantly decreased thereafter, whereas for summer-greens shoot density was rather stable during the whole growing season (Figure 4). The shoot density peak for Anemone nemorosa was observed on April 10, 2010, and May 14, 2011 , but similar values were observed during April and May (Figure 5, Table A5).

The highest ANPP values were obtained by the 6th method, based on the sum of maximal products of shoot biomass and density for each species. The ANPP obtained by the 6th method was 74.3 and 


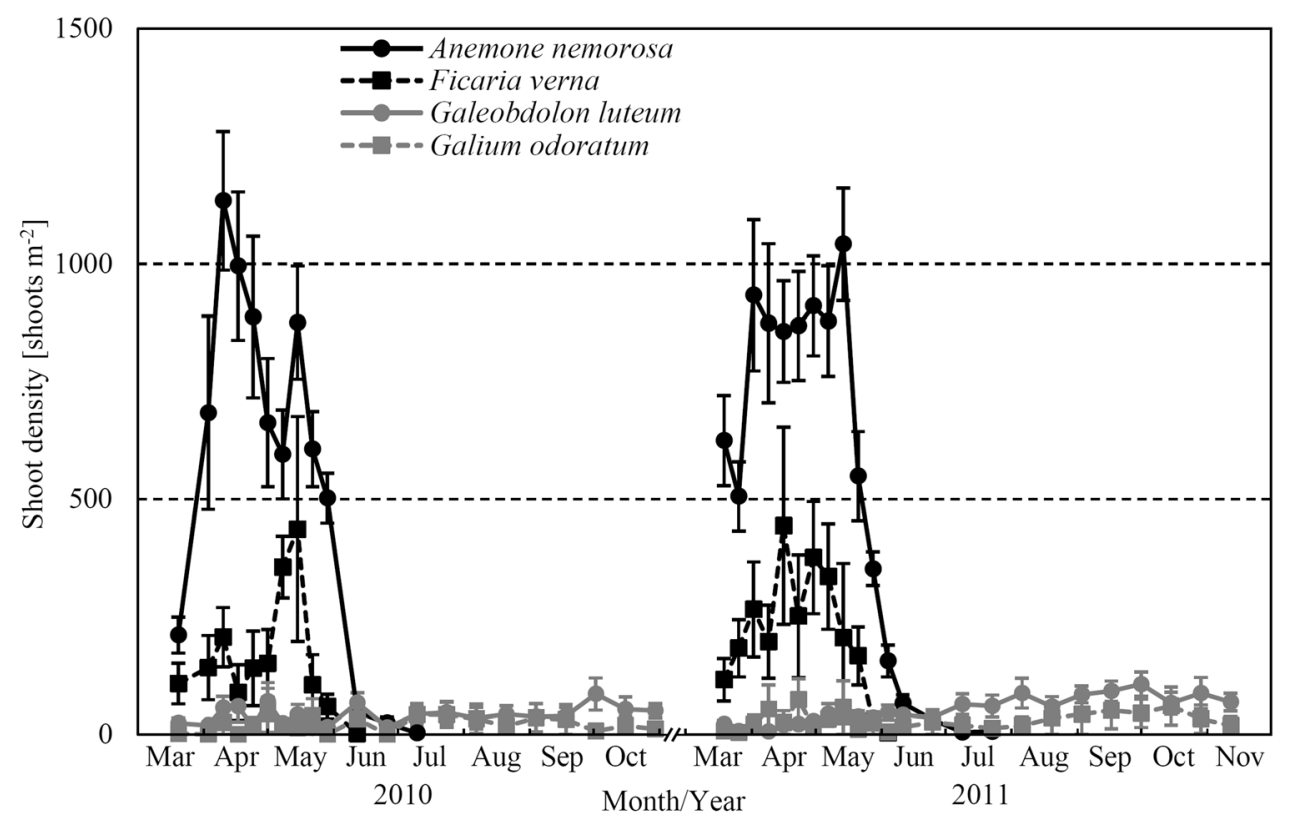

Figure 5. The seasonal dynamics of shoot densities of dominant herb layer species: two spring ephemerals: Anemone nemorosa and Ficaria verna, and two summer-greens: Galeobdolon luteum and Galium odoratum. The points represent mean values and the vertical lines represent the standard error of the mean.

$94.0 \mathrm{~g} \mathrm{~m}^{-2}$ year $^{-1}$ in in 2010 and 2011 , respectively, which were $96 \%$ and $129 \%$ higher than values obtained by the 1st method, 2010 and 2011 , respectively (Table 3). Similarly, as in all previous methods Anemone nemorosa had the dominant share of ANPP; it comprised $46 \%$ of the total ANPP in 2010 and 50\% in 2011. Summer-greens had lower shares of ANPP: Galeobdolon luteum reached 9\% in both years; Galium odoratum reached 5\% in 2010 and $6 \%$ in 2011; and Mercurialis perennis reached $10 \%$ in 2010 and $2 \%$ in 2011 (Table A6).

\section{Discussion}

The highest aboveground current year, herb layer stand biomass was $37.8 \mathrm{~g} \mathrm{~m}^{-2}$ in 2010 and $41.0 \mathrm{~g} \mathrm{~m}^{-2}$ in 2011 . The highest share of peak biomass was the spring ephemeral Anemone nemorosa, $64 \%$ in 2010 and $65 \%$ in 2011 . The seasonal herb layer biomass dynamic shows a twopeak shape; a bigger peak occurred in spring and was composed of spring ephemerals and a lesser peak occurred in late summer or early autumn and was composed of summer-greens. Estimation of ANPP based on seasonal increments of herb layer biomass gave higher values $\left(50.2 \mathrm{~g} \mathrm{~m}^{-2}\right.$ year $^{-1}$ in 2010 and $58.3 \mathrm{~g} \mathrm{~m}^{-2}$ year $^{-1}$ in 2011) than one time sampling at the time of peak biomass. Taking into account biomass dynamics of individual species and their specific biomass peaks gave ANPP values of $59.8 \mathrm{~g} \mathrm{~m}^{-2}$ year $^{-1}$ in 2010 and $72.6 \mathrm{~g} \mathrm{~m}^{-2}$ year $^{-1}$ in 2011 . Accounting for maximal products of shoot density and shoot biomass for individual species gave the highest ANPP values: $74.3 \mathrm{~g} \mathrm{~m}^{-2}$ year ${ }^{-1}$ in 2010 and $94.0 \mathrm{~g} \mathrm{~m}^{-2}$ year $^{-1}$ in 2011 .

The majority of previous studies focused on herb layer standing biomass at one or a few dates per year. The highest herb layer biomass obtained by Kaźmierczakowa (1971) in an oak-hornbeam forest in southern Poland was $63 \mathrm{~g} \mathrm{~m}^{-2}$ in 1965 and $24 \mathrm{~g} \mathrm{~m}^{-2}$ in 1967. The drastically lower biomass value in 1967 was caused by pathogenic fungi which infected herbaceous plants. The result obtained in 1965 was one and a half times higher than the biomass values in our study. The reason for these differences is the dominance of $\mathrm{Ae}$ gopodium podagraria, which creates larger shoots than Anemone nemorosa, which is dominant in our study. Even higher values of herb layer biomass were obtained by Werger and van Laar (1985) in an oak-hornbeam forest in the Netherlands-133.9 $\mathrm{g} \mathrm{m}^{-2}$, where the dominant herb was Allium ursinum, which creates dense foliage and taller shoots than Anemone nemorosa. Landyut and others (2020) reported that the median value of herb layer aboveground biomass from 19 sites of mesic forests in northwestern Europe was $63.8 \mathrm{~g} \mathrm{~m}^{-2}$. Herb layer biomass in the cited study varied from 0 to almost $500 \mathrm{~g} \mathrm{~m}^{-2}$. These results show high variability of herb layer biomass, even in 
one type of forest. One of the reasons is varied species composition, especially different dominant species.

Fewer papers have focused on productivity of the herb layer. The often used method in ANPP estimation is based on the sum of products of shoot biomass and shoot density of individual species in the term when shoot biomass is the highest-assumed as time after the peak of flowering (Traczyk 1967a). The 4th method used in this study was calculated similarly and had ANPP values of $52.7 \mathrm{~g} \mathrm{~m}^{-2}$ year $^{-1}$ in 2010 and $72.7 \mathrm{~g} \mathrm{~m}^{-2}$ year $^{-1}$ in 2011. Traczyk (1971) used products of shoots biomass and density and obtained ANPP values of $72.4 \mathrm{~g} \mathrm{~m}^{-2}$ year $^{-1}$ in a moist oak-hornbeam forest and $57.5 \mathrm{~g} \mathrm{~m}^{-2}$ year $^{-1}$ in a drier oak-hornbeam forest in northeastern Poland. Lower ANPP values were obtained by Banasik and Jankowska (1978), who had used a similar method in an oak-hornbeam forest in southern Poland and obtained $46.1 \mathrm{~g} \mathrm{~m}^{-2}$ year $^{-1}$ in a moist type and $23.8 \mathrm{~g} \mathrm{~m}^{-2}$ year $^{-1}$ in a drier type. An even lower ANPP value was obtained by Traczyk (1967b), with a similar method in an oak-hornbeam forest in centraleastern Poland, of $16.7 \mathrm{~g} \mathrm{~m}^{-2}$ year $^{-1}$. This low ANPP was caused by sparse vegetation in the herb layer. The fact that results of studies show a wide range of ANPP in oak-hornbeam forests due to varied fertility, moisture, and herb layer species composition, underlines the need for deeper studies on the productivity of the herb layer in forests.

Besides the variability of ANPP among sites, ANPP also shows variation in time between seasons due to varying meteorological conditions in various forest types. For example, Aulak (1976) conducted a three-year study of the herb layer ANPP in an oak-hornbeam forest in eastern Poland (Białowieża National Park) and obtained the following ANPP values: $38.7,83.4$ and $99.1 \mathrm{~g} \mathrm{~m}^{-2}$ year $^{-1}$ in 1971, 1972, and 1973, respectively. The assumed reason for the low ANPP value in 1971 was low precipitation during spring and summer. In our study, we noted higher ANPP in 2011 than in 2010, by 8 to $38 \%$ depending on the method used. The spring of 2011 was characterized by lower precipitation (but not drought) and a higher mean monthly temperature than spring of 2010. Higher temperatures and a higher portion of sunny days may translate into higher ANPP of the herb layer in 2011 than in 2010.

In the herb layer of fertile deciduous forests, species occur with different strategies to live in stressful conditions, caused by limited light availability on the forest floor (Neufeld and Young 2014; Popović and others 2016). Spring ephemerals use a period of early spring before full canopy development when temperature conditions are beneficial for plant growth and light transmittance to the forest floor is not blocked by canopy foliage (Mahall and Bormann 1978; Richardson and O'Keefe 2009). Summer-greens are physiologically adapted to limited light availability on the forest floor beneath tree canopy foliage (Kudo and others 2008; Rothstein and Zak 2001). These strategies are reflected in the seasonal dynamics of biomass. In our study, we observed a clear peak of total biomass in the first half of May, and spring ephemerals were responsible for the majority of that peak. The second, less apparent peak of biomass was noticed in September and October, and summer-greens were responsible for that peak. Timing of biomass peaks are specific for particular species; for example, $A n$ emone nemorosa biomass peaked at the end of April to first half of May, Galeobdolon luteum biomass peaked in September-October, and Mercurialis perennis peaked from the second half of June to the first half of July. Hughes (1975), in Danish fertile beech forest, analyzed the seasonal dynamics of above- and belowground biomass of the herb layer and observed biomass peaks in June (the larger one) and October (lesser one). For example, in that study, Anemone nemorosa biomass (above and belowground together) peaked in June, Melica uniflora in July, and Oxalis acetosella and Carex sylvatica in October. These results showed a variety of biomass seasonal dynamics depending on species. Tremblay and Larocque (2001), in a fertile deciduous forest in eastern Canada, observed two peaks of herb layer biomass in May and in September, whereas they reported only one peak of biomass in coniferous stands. That showed a connection between the seasonal dynamics of canopy foliage and herb layer biomass dynamics.

The temporal variability of biomass peaks for herb layer species causes methods based on one time measurement of herb layer biomass to give an underestimation of the ANPP. Methods of estimating ANPP biomass based on several biomass collection times have advantages over single collection times. For example, with several collection times we can sum positive differences between biomass in consecutive times of collection, taking into account biomass increments between biomass peaks. This method does not require a separate collection of individual species; the entire herbaceous biomass can be collected in total. This method may overestimate ANPP taking into account differences resulting from spatial variability of herb layer biomass. These differences will not be reduced because we summed only increments of 
biomass; we did not sum declines of biomass. More complicated methods require separate collections of individual species. In this way, we can trace the dynamics of biomass for individual species and determine biomass peaks for all species individually. Even more laborious methods need a determination of shoot biomass and density. In the method proposed by Traczyk (1967a) density of shoots is determined at one time and shoot biomass also once but at different times, depending on plant species, at the time when shoot biomass is highest. That procedure allows carrying out a large number of density measure samples without biomass collection, thereby reducing the labor intensity of field work. The heterogeneity of the herb layer and thus the large variation of results require collection of numerous samples, while shoot biomass is less variable, so can be estimated on a lower number of samples (shoots). The time when shoot biomass is the highest is assumed to be just after the peak of flowering (Traczyk 1967a); however, Aulak (1976) found that this assumption did not always hold true. For example, Galeobdolon luteum flowered at the turn of May and June, but the shoot biomass peak was in September. To account for this, we tracked the shoot biomass of all registered species over two growing seasons and used the absolute highest shoot biomass for calculations. Aulak (1976) showed that the highest shoot biomass occurred with a decreasing shoot density. This is due to the early dieback of smaller shoots so that the highest shoot biomass is after the peak of shoot density. An important issue in the methods using the products of shoot biomass and density is what time of measurements should be used for calculations. In our study, we showed results for ANPP using calculations based on times when the shoot biomass was the highest, when shoot density was the highest, and when the product of shoot biomass and density was the highest. The last method gave us the significantly highest ANPP results. The two previous methods gave ANPP results quite similar to the one based on the biomass dynamics of individual species. The last method seems to give the results closest to the real ANPP. Aulak (1976) obtained similar value relationships between the methods used and presented a similar ANPP value as in our last method, using an even more accurate method of tracking individuals of each species. The 6th method eliminates disadvantages of 4 th and 5 th methods based on products of shoot density and shoot biomass and can be recommended as the most accurate method for estimating ANPP.

Our results showed that the estimation of ANPP in the herb layer of deciduous forests needs track- ing of the seasonal dynamics of individual species. Due to the different strategies of species living in a restricted light environment, species have different biomass dynamics and reach biomass peaks at different times. Using the maximum amount of biomass as the ANPP causes a 50\% underestimation of ANPP. A good method, and not requiring large amounts of work, seems to be a method based on the dynamics of the biomass of individual species. Nevertheless, estimating the ANPP is a difficult and laborious matter and commonly used methods usually give underestimated values. Therefore, as much as twofold underestimation may occur with regard to the roles of the herb layer in, for example, carbon accumulation and nutrient cycling.

\section{ACKNOWLEDGEMENTS}

The study was financially supported by the Institute of Dendrology, Polish Academy of Sciences, Kórnik, Poland. We thank Aneta Rawlik and Zbigniew Rawlik for valuable help in field works, and Katarzyna Rawlik for help in laboratory works. We would like to thank Dr. Lee E. Frelich (The University of Minnesota Center for Forest Ecology, USA) for linguistic revision of the manuscript.

\section{AVAILABILITY DATA AND MATERI- ALS}

Source data of research are available on figshare: https://doi.org/10.6084/m9.figshare.14627052.v1. Full citation: Rawlik and others (2021): ANPP.xlsx. figshare. Dataset. https://doi.org/10.6084/m9.figsh are.14627052.v1.

\section{Declarations}

Conflict of interest The authors declare that they have no conflict of interest.

\section{OPEN ACCESS}

This article is licensed under a Creative Commons Attribution 4.0 International License, which permits use, sharing, adaptation, distribution and reproduction in any medium or format, as long as you give appropriate credit to the original author(s) and the source, provide a link to the Creative Commons licence, and indicate if changes were made. The images or other third party material in this article are included in the article's Creative Commons licence, unless indicated otherwise in a credit line to the material. If material is not included in the article's Creative Commons licence 
and your intended use is not permitted by statutory regulation or exceeds the permitted use, you will need to obtain permission directly from the copyright holder. To view a copy of this licence, visit http://creativecommons.org/licenses/by/4.0/.

\section{REFERENCES}

Aulak W. 1970. Studies on herb layer production in the CircaeoAlnetum Oberd. 1953 associations. Ekologia Polska 18(19): $411-427$.

Aulak W. 1976. Rozwój i produkcja runa w zespole TilioCarpinetum Tracz. 1962 jako jednego z elementów podstawowego poziomu troficznego w ekosystemach leśnych. Zeszyty Naukowe Szkoły Głównej Gospodarstwa Wiejskiego Akademii Rolniczej w Warszawie 60:1-151.

Axmanová I, Zelený D, Li C-F, Chytrý M. 2011. Environmental factors influencing herb layer productivity in Central European oak forests: insights from soil and biomass analyses and a phytometer experiment. Plant and Soil 342:183-194. https://d oi.org/10.1007/s11104-010-0683-9.

Banasik J, Jankowska K. 1978. Produkcja netto runa lasu grądowego w rezerwacie Lipówka w Puszczy Niepołomickiej. Studia Naturae 17:135-146.

Banasik J. 1978. Sezonowy rozwój i produkcja netto runa w dwóch płatach lasu grądowego Puszczy Niepołomickiej. Studia Naturae 14:67-132.

Boch S, Berlinger M, Fischer M, Knop E, Nentwig W, Türke M, Prati D. 2013. Fern and bryophyte endozoochory by slugs. Oecologia 172(3):817-822. https://doi.org/10.1007/s00442-0 12-2536-0.

Central Statistical Office. 2011. Statistical Yearbook of the Republic of Poland. Statistical Publishing Establishment. Warszawa. https://stat.gov.pl/cps/rde/xbcr/gus/rs_rocznik_sta tystyczny_rp_2011.pdf. Accessed 17 Jan 2020.

Central Statistical Office. 2012. Statistical Yearbook of the Republic of Poland. Statistical Publishing Establishment. Warszawa. https://stat.gov.pl/cps/rde/xbcr/gus/RS_rocznik_st atystyczny_rp_2012.pdf. Accessed 17 Jan 2020.

Clark DA, Brown S, Kicklighter DW, Chambers JQ, Thomlinson JR, Ni J. 2001. Measuring net primary production in forests: Concepts and field methods. Ecological Applications 11:356370. https://doi.org/10.1890/1051-0761(2001)011[0356:MN PPIF]2.0.CO;2.

Dąbrowski MJ. 1953. Badania nad biomasą runa prowadzone przez Filię Instytutu Badawczego Leśnictwa w Białowieży. Ekologia Polska 1(1):45-56.

Dzięciołowski R. 1970. Biomass of herb layer and understory plants as potential food resources for herbivorous mammals. Folia Forestalia Polonica A 16:69-90.

Elliott KJ, Vose JM, Knoepp JD, Clinton BD, Kloeppel BD. 2015. Functional role of the herbaceous layer in eastern deciduous forest ecosystems. Ecosystems 18:221-236. https://doi.org/10. 1007/s10021-014-9825-x.

Franklin JA, Zipper CE, Burger JA, Skousen JG, Jacobs DF. 2012. Influence of herbaceous ground cover on forest restoration of eastern US coal surface mines. New Forests 43:905-924. https://doi.org/10.1007/s11056-012-9342-8.

Gilliam FS. 2007. The ecological significance of the herbaceous layer in temperate forest ecosystems. BioScience 57:845-858. https://doi.org/10.1641/B571007.
Halpern CB, Spies TA. 1995. Plant species diversity in natural and managed forests of the Pacific Northwest. Ecological Applications 5(4):913-934.

Hanes JM, Richardson AD, Klosterman S. 2013. Mesic Temperate Deciduous Forest Phenology. In: Schwartz M. (eds) Phenology: An Integrative Environmental Science. Dordrecht, Netherlands: Springer. https://doi.org/10.1007/978-94-007-6 925-0_12

Hermy M, Honnay O, Firbank L, Grashof-Bokdam C, Lawesson JE. 1999. An ecological comparison between ancient and other forest plant species of Europe, and the implications for forest conservation. Biological Conservation 91:9-22. https:// doi.org/10.1016/S0006-3207(99)00045-2.

Hermy M, Verheyen K. 2007. Legacies of the past in the presentday forest biodiversity: a review of past land-use effects on forest plant species composition and diversity. Ecological Research 22:361-371. https://doi.org/10.1007/s1 1284-007-0354 $-3$.

Hughes MK. 1975. Ground vegetation net production in a Danish beech wood. Oecologia 18:251-258.

IMGW-PIB, Instytut Meteorologii i Gospodarki Wodnej Państwowy Instytut Badawczy. 2020. https://danepubliczne. imgw.pl/data/dane_pomiarowo_obserwacyjne/. Accessed 25 Sep 2020.

Jacob M, Leuschner C, Thomas FM. 2010. Productivity of temperate broad-leaved forest stands differing in tree species diversity. Annals of Forest Science 67(5):503. https://doi.org/ $10.1051 /$ forest/2010005.

Jagodziński AM, Dyderski MK, Rawlik K, Kạtna B. 2016. Seasonal variability of biomass, total leaf area and specific leaf area of forest understory herbs reflects their life strategies. Forest Ecology and Management 374:71-81. https://doi.org/ 10.1016/j.foreco.2016.04.050

Jagodziński AM, Pietrusiak K, Rawlik M, Janyszek S. 2013. Seasonal changes in the understorey biomass of an oakhornbeam forest Galio sylvatici-Carpinetum betuli. Forest Research Papers 74(1):35-47. https://doi.org/10.2478/frp-20130005 .

Kaźmierczakowa R. 1971. Ekologia i produkcja runa świetlistej dạbrowy i grądu w rezerwatach Kwiatówka i Lipny Dół na Wyżynie Małopolskiej. Studia Naturae 5:1-104.

Kollár J, Kubíček F, Šimonovič V, Kanka R, Balkovič J. 2010. Production-ecological analysis of the broad-leaved forest ecosystems herb layer biomass in the Žalostínska vrchovina upland and Zámčisko (Western Slovakia). Ekológia (Bratislava) 29(2):113-122. https://doi.org/10.4149/ekol_2010_02_11 3.

Kubíček F, Jurko A. 1975. Estimation of the above-ground biomass of the herb layer in forest communities. Folia Geobotanica Et Phytotaxonomica 10:113-129.

Kudo G, Ida TY, Tani T. 2008. Linkages between phenology, pollination, photosynthesis, and reproduction in deciduous forest understory plants. Ecology 89:321-331. https://doi.org/ 10.1890/06-2131.1.

Landuyt D, De Lombaerde E, Perring MP, Hertzog LR, Ampoorter E, Maes SL, De Frenne P, Ma S, Proesmans W, Blondeel H, Sercu BK, Wang B, Wasof S, Verheyen K. 2019. The functional role of temperate forest understorey vegetation in a changing world. Global Change Biology 25:3625-3641. https://doi.org/10.1111/gcb.14756.

Landuyt D, Maes SL, Depauw L, Ampoorter E, Blondeel H, Perring MP, Brūmelis G, Brunet J, Decocq G, Ouden J, Härdtle W, Hédl R, Heinken T, Heinrichs S, Jaroszewicz B, Kirby KJ, 
Kopecký M, Máliš F, Wulf M, Verheyen K. 2020. Drivers of above-ground understorey biomass and nutrient stocks in temperate deciduous forests. Journal of Ecology 108:982-997. https://doi.org/10.1111/1365-2745.13318.

Mahall BE, Bormann FH. 1978. A quantitative description of the vegetative phenology of herbs in a northern hardwood forest. Botanical Gazette 139(4):467-481. https://doi.org/10.1086/3 37022.

Mayer PM. 2008. Ecosystem and decomposer effects on litter dynamics along an old field to old-growth forest successional gradient. Acta Oecologica 33:222-230. https://doi.org/10.101 6/j.actao.2007.11.001.

Muller RN. 2014. Nutrient relations of the herbaceous layer in deciduous forest ecosystems. In: Gilliam FS, Roberts MR, Eds. The Herbaceous Layer in Forests of Eastern North America. New York, USA: Oxford University Press. pp 13-34.

Neufeld HS, Young DR. 2014. Ecophysiology of the herbaceous layer in temperate deciduous forests. In: Gilliam FS, Roberts MR, Eds. The Herbaceous Layer in Forests of Eastern North America. New York, USA: Oxford University Press. pp 35-95.

Plan Urządzenia Lasu dla Nadleśnictwa Różańsko wg stanu na dzień 01.01.2006 na okres 2006-2015. 2006. Przedsiębiorstwo Wielobranżowe Krameko. Manuscript in Nadleśnictwo Różańsko.

Popović Z, Bojović S, Matić R, Stevanović B, Karadžić B. 2016. Comparative ecophysiology of seven spring geophytes from an oak-hornbeam forest. Brazilian Journal of Botany 39:29-40. h ttps://doi.org/10.1007/s40415-015-0204-4.

Rajchel R. 1965. Produktywność pierwotna netto runa w dwóch zespołach leśnych Ojcowskiego Parku Narodowego. Fragmenta Floristica Et Geobotanica 11(1):121-150.

Rawlik K, Nowiński M, Jagodziński AM. 2021. Short life - fast death. Decomposition rates of woody plants leaf- and herblitter. Annals of Forest Sciences 78: 6. https://doi.org/10.1007/ s13595-020-01019-y

Rawlik M, Jagodziński AM, Janyszek S. 2012. Seasonal changes in the understorey biomass of an oak-hornbeam forest Stellario holosteae-Carpinetum betuli. Forest Research Papers 73(3):221235. https://doi.org/10.2478/v10111-012-0022-4.

Rawlik M, Jagodziński AM. 2020. Seasonal dynamics of shoot biomass of dominant clonal herb species in an oak-hornbeam forest herb layer. Plant Ecology 221:1133-1142. https://doi. org/10.1007/s1 1258-020-01067-4.

Reich PB, Frelich L. 2002. Temperate Deciduous Forests. In: Munn T. (eds) Encyclopedia of Global Environmental Change. Chichester, United Kingdom: John Wiley \& Sons.

Richardson AD, O'Keefe J. 2009. Phenological differences between understory and overstory: a case study using the longterm Harvard forest records. In: Noormets A, Ed. Phenology of Ecosystem Processes. New York, USA: Springer. pp 87-117.

Rothstein DE, Zak DR. 2001. Photosynthetic adaptation and acclimation to exploit seasonal periods of direct irradiance in three temperate, deciduous-forest herbs. Functional Ecology 15:722-731. https://doi.org/10.1046/j.0269-8463.2001.00584 .x.
Schnitzler A, Hale BW, Alsum EM. 2007. Examining native and exotic species diversity in European riparian forests. Biological Conservation 118:146-156. https://doi.org/10.1016/j.biocon. 2007.04.010

Smolko P, Veselovská A, Kropil R. 2018. Seasonal dynamics of forage for red deer in temperate forests: importance of the habitat properties. stand development stage and overstorey dynamics. Wildlife Biology 2018(1): wlb.00366. https://doi. org/10.2981/wlb.00366

Solon J, Borzyszkowski J, Bidłasik M, Richling A, Badora K, Balon J, Brzezińska-Wójcik T, Chabudziński Ł, Dobrowolski R, Grzegorczyk I, Jodłowski M, Kistowski M, Kot R, Krąż P, Lechnio J, Macias A, Majchrowska A, Malinowska E, Migoń P, Myga-Piątek U, Nita J, Papińska E, Rodzik J, Strzyż M, Terpiłowski S, Ziaja W. 2018. Physico-geographical mesoregions of Poland - verification and adjustment of boundaries on the basis of contemporary spatial data. Geographia Polonica 91(2):143-170.

Thrippleton T, Bugmann H, Kramer-Priewasser K, Snell RS. 2016. Herbaceous understorey: an overlooked player in forest landscape dynamics? Ecosystems 19(7):1240-1254.

Tibco Software Inc. 1984-2017. STATISTICA (data analysis software system), version 13.3. https://www.tibco.com/

Traczyk H. 1971. Relation between production and structure of herb layer in associations on "The Wild Apple-Tree Island" (Masurian Lake District). Ekologia Polska 19(25):333-363.

Traczyk T. 1967a. Propozycja nowego sposobu oceny produkcji runa. Ekologia Polska - seria B 13(3): 241-247.

Traczyk T. 1967b. Studies on herb layer production estimate and size of plant fall. Ekologia Polska - seria A 15(47): 836-867.

Tremblay NO, Larocque GR. 2001. Seasonal dynamics of understory vegetation in four eastern Canadian forest types. International Journal of Plant Sciences 162(2):271-286.

Uemura S. 1994. Patterns of leaf phenology in forest understory. Canadian Journal of Botany 72(4):409-414. https://doi.org/ 10.1139/b94-055.

Welch NT, Belmont JM, Randolph JC. 2007. Summer ground layer biomass and nutrient contribution to above-ground litter in an Indiana temperate deciduous forest. The American Midland Naturalist 157:11-26. https://doi.org/10.1674/00030031(2007)157[11:SGLBAN]2.0.CO;2.

Werger MJA, van Laar EMJM. 1985. Seasonal changes in the structure of the herb layer of a deciduous woodland. Flora 176:351-364.

Whigham DF. 2004. Ecology of woodland herbs in temperate deciduous forests. Annual Review of Ecology, Evolution, and Systematics 35:583-621. https://doi.org/10.1146/annurev.ec olsys.35.021103.105708.

Woodward FI, Lomas MR, Kelly CK. 2004. Global climate and the distribution of plant biomes. Philosophical Transactions of the Royal Society of London. Series B: Biological Sciences 359:1465-1476. https://doi.org/10.1098/rstb.2004.1525. 